\title{
VERSITA
}

DOI: $10.2478 / v 10299-012-0023-0$

\section{The Characteristics of Air Swirl Supply Device}

\author{
Orest Voznyak, Iryna Sukholova, Khrystyna Myroniuk \\ National University "Lviv Polytechnic" \\ Institute of Building and Environmental Engineering, Chair "Heat, Gas supply and ventilation" \\ e-mail: orest.voznyak@i.ua
}

\begin{abstract}
In this article results of experimental investigations of air supply into the room by air distribution device which creates swirl air jets for creation more intensive turbulization air flow in the room are presented. Experimental investigations in order to composed matrix were carried out; graphycal dependences have been obtained as well three-factor chart has been designed. Obtained results of these investigations give possibility to realize engineer calculations of air distribution with swirl air jets.
\end{abstract}

Key words: air distribution device, swirl air jet, air jet characteristics

\section{Introduction}

For creation comfortable conditions in an apartment, capital and operating costs reduction we need to provide effective air supply in an apartment. During designing ventilation and conditioning systems customers and designers don't pay enough attention to the question of air supply. To determine the amount of supply air it is necessary to take into account the choice of a scheme of ventilation organization.

Sanitary-hygienic and energy efficiency of ventilation system depends on the correct choice of chart of air supply organization and of air supply method. The choice of air supply device and it's location is very important. The temperature of supply air depends on air supply device location [2].

To choose air distribution method we should take into account the features of apartment, it's setting, structural features, location and size of warmth, moisture, harmful gases sources. 


\section{Analyses of the last researches and publications}

One of the most rational way of air distribution is submission of coming air directly in a room serviced zone. As characteristic property of such incoming air jet there is it's higher turbulent in comparison with common air jets $[3,5,6,7,8]$.

For this purpose air distribution devices with high intensity of falling of velocity and temperature of incoming air are used. Swirl air distribution devices provide intensive interfusion of incoming air with surrounding [1]. Using swirl air jets is one of methods to increase turbulent of incoming air flow.

Coefficient of velocity going out of air supply device that forms swirl air jet is determined

$$
\mathrm{m}=\frac{\mathrm{Vx}}{\mathrm{Vo}} \frac{\mathrm{X}}{\sqrt{\mathrm{F}}}
$$

and coefficient of temperature going out is determined

$$
\mathrm{n}=\frac{\Delta \mathrm{tx}}{\Delta \mathrm{to}} \frac{\mathrm{X}}{\sqrt{\mathrm{F}}}
$$

where $\mathrm{V}_{\mathrm{x}}, \mathrm{V}_{\mathrm{o}}$ - is velocity on the axis of air jet and initial velocity;

$\Delta \mathrm{t}_{\mathrm{x}}, \Delta \mathrm{t}_{\mathrm{o}}$ - is surplus temperature on the axis of air jet and initial surplus temperature.

In this work we consider aspect of raising air distribution effect in the apartment with air flow turbulization by using swirl air jets. The question of velocity distribution in an apartment decides, coefficient of velocity and temperature going out account.

As a result of using swirl air distribution devices is creating total air flow, which is directly applied in the working area. The principal concern in this work is to investigate relation between air supply device characteristics and total air flow.

\section{Aim and tasks of researches}

The purpose of this work is to study the characteristics of air swirl supply device, to determine the going out coefficients of air flow velocity and temperature at different cases of swirling.

\section{Presentation of the main material}

Experimental research has been carried out on the installation, that is presented on fig. 1, fig.

2, under such conditions and simplifications:

- jets are non-isotermic;

- the linear sizes of air supply device did not change;

- the angle of slope of swirling plates changed; a circular crack was closed. 


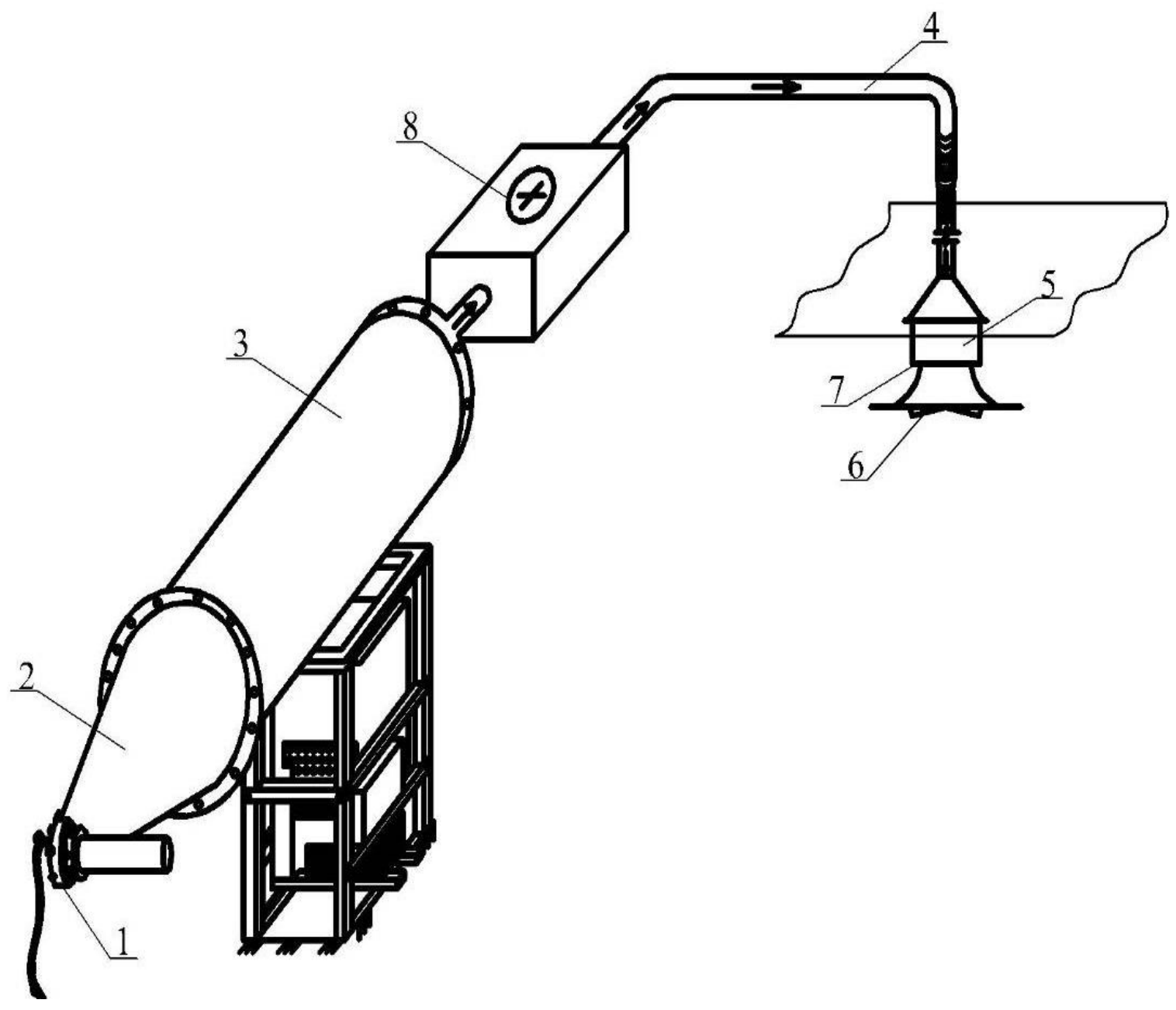

Figure 1: Scheme of experimental installation

1 - ventilator; 2 - contractor; 3 - chamber of static pressure; 4 - collector (flexible hose); 5 air supply device; 6 - swirl plates; 7 - circular crack; 8 - heater

The gaugings of air flow velocity $\mathrm{V}$ were carried out by thermal electric anemometer testo405 with using coordinate grid of $10 \times 10 \mathrm{sm}$.

For realization of experimental investigations 3-factor chart has been designed taking into account the effect of factor interaction. As the starting point were taken such values:

- $x_{1}=\bar{X}=\mathrm{x} / l$ - relative vertical running data, where $\mathrm{x}$ - vertical distance from air supply device to point, where air flow velocity conducted; $l$ - general vertical distance from air supply device to working zone;

- $\quad x_{2}=\bar{Y}=\mathrm{y} / b-$ relative horizontal running data, where $\mathrm{y}-$ horizontal distance from air supply device to point, where air flow velocity conducted; $b$ - general horizontal distance from air supply device to working zone;

- $\quad x_{3}=\alpha-$ the angle of slope of swirling plates.

Going out coefficients of air flow velocity and temperature are counted with equations (1) and (2). 


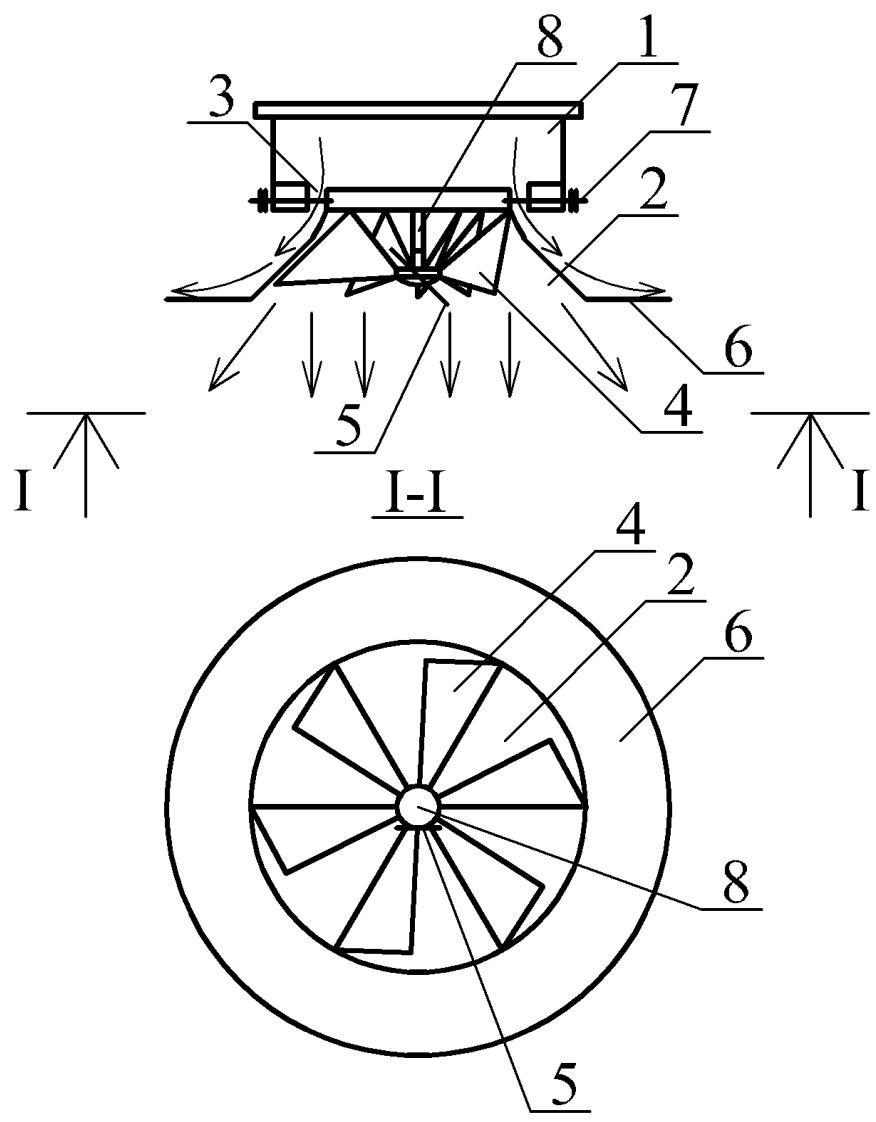

Figure 2: Scheme of swirl air distribution device

Table 1: 3-factor matrix of planning for axia velocity determination

\begin{tabular}{|c|c|c|c|c|c|c|c|c|c|c|}
\hline$№$ & $x_{0}$ & $x_{1}=$ & $x_{2}=$ & $x_{3}=$ & $x_{1} x_{2}$ & $x_{1} x_{3}$ & $x_{2} x_{3}$ & $x_{1} x_{2} x_{3}$ & $\bar{V}_{a x}$ & $\Delta \bar{t}$ \\
$\overline{\bar{x}}=x / l$ & $\bar{y}=y / b$ & $\bar{\alpha}$ & & & & & & \\
\hline 1 & + & - & - & - & + & + & + & - & 1,0 & 1,0 \\
\hline 2 & + & + & - & - & - & - & + & + & 0,21 & 0,33 \\
\hline 3 & + & - & + & - & - & + & - & + & 1,0 & 1,0 \\
\hline 4 & + & + & + & - & + & - & - & - & 0,52 & 0,64 \\
\hline 5 & + & - & - & + & + & - & - & + & 1,0 & 1,0 \\
\hline 6 & + & + & - & + & - & + & - & - & 0,1 & 0,1 \\
\hline 7 & + & - & + & + & - & - & + & - & 1,0 & 1,0 \\
\hline 8 & + & + & + & + & + & + & + & + & 0,52 & 0,52 \\
\hline
\end{tabular}




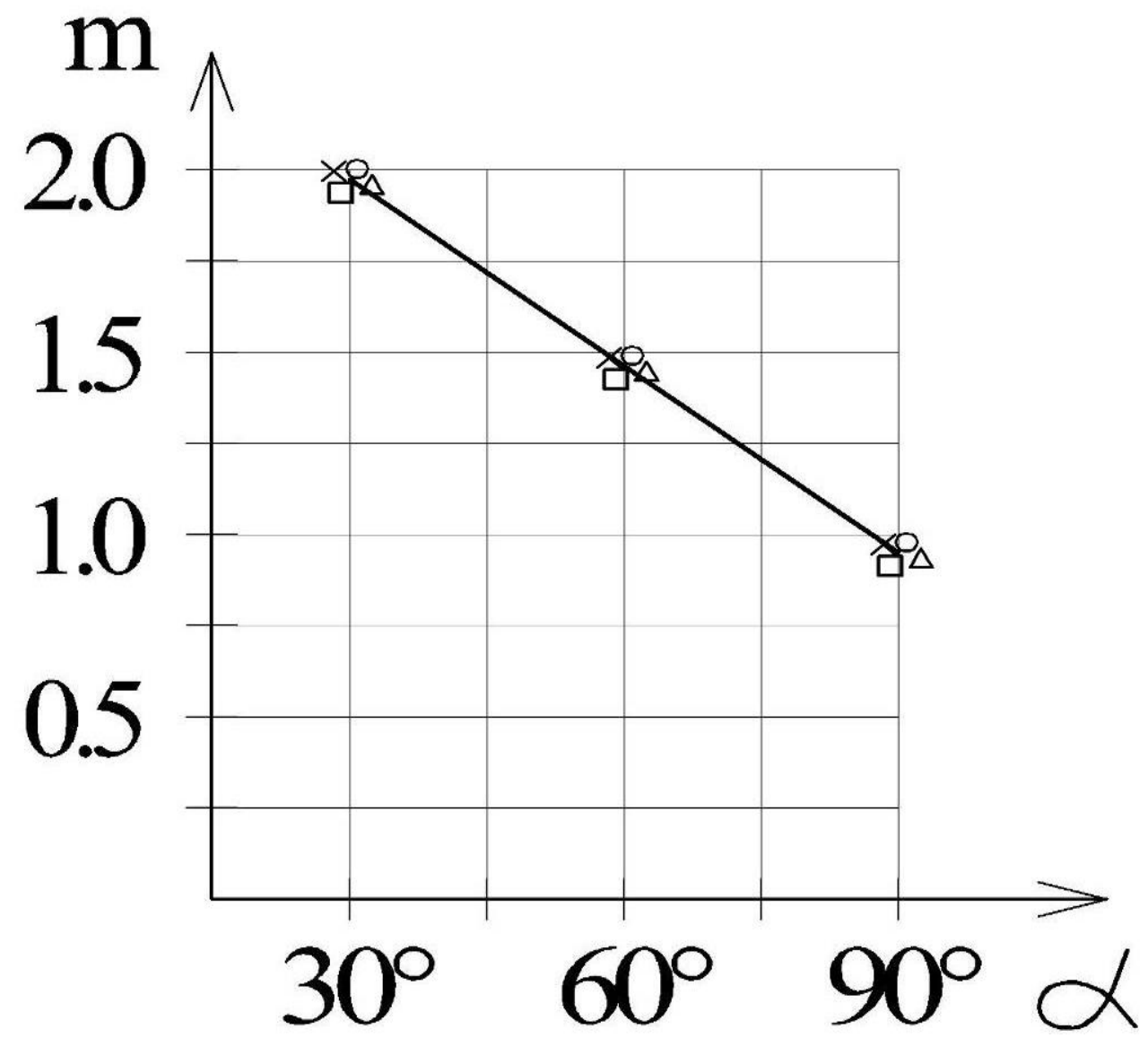

Figure 3: Chart for determination of going out coefficient of air flow velocity $\mathrm{m}$

As a result of experimental research and calculations charts for going out coefficients of air flow velocity and temperature have been designed fig. 3, fig. 4 .

Air with the help of ventilator (1) (direct-current motor) goes to chamber of static pressure (3), where air flow smoothing, after air flow goes to heater (8), and then through a flexible air-channel (4) in investigated swirl air supply device (5).

The matrix of experiment planning consists of series of experiments. The dispersion of total experiment gets as an average dispersion result of all experiments. It's dispersion of optimization parameter.

Homogeneity of dispersions check up with data of static criteria. The simplest is Fisher criteria (F-criteria). It shows the attitude of greater dispersion toward less. Calculated number is compared to tabular.

Maximal dispersion appeared in experiment № 7. $D_{7}=0,0018$ 


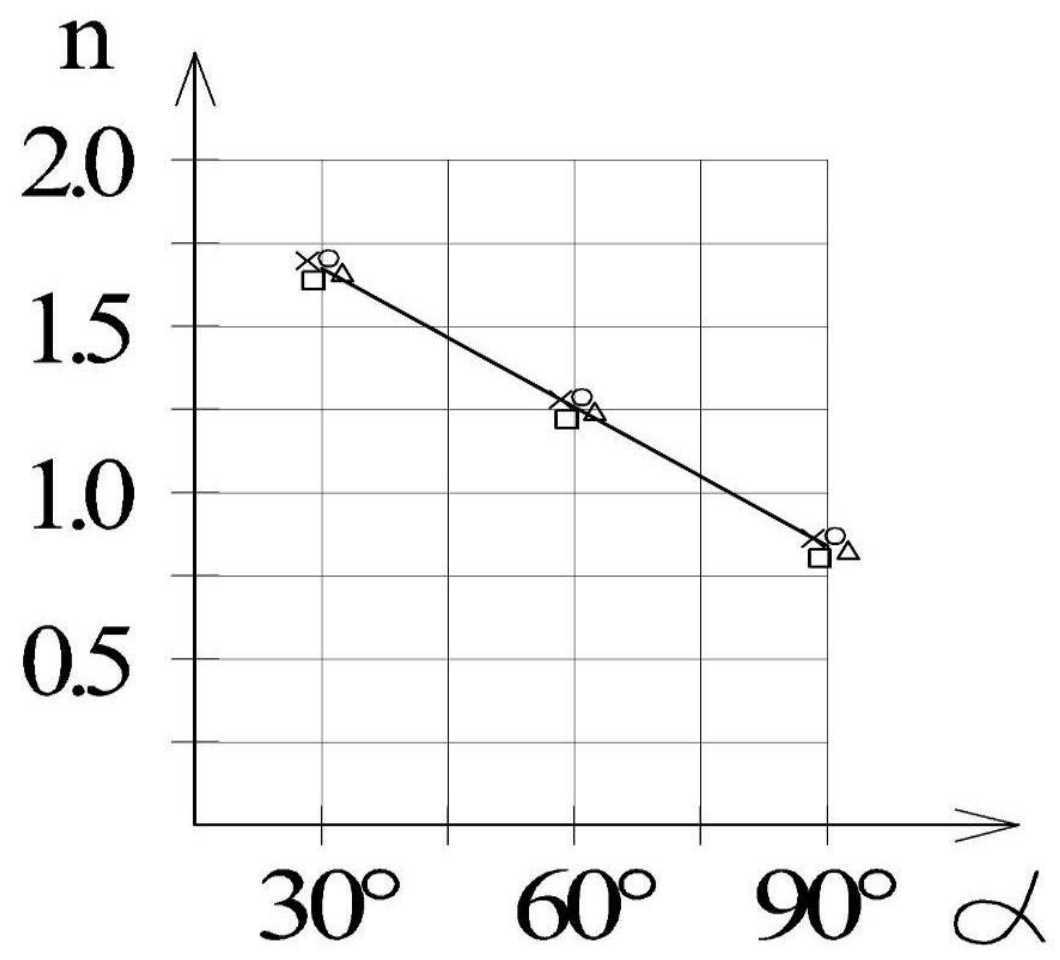

Figure 4: Chart for determination of going out coefficient of air flow temperature $n$

Table 2: Calculation of producibility dispersion $S_{1}^{2}=2 \times \Delta y^{2}$

\begin{tabular}{|c|c|c|c|c|c|c|}
\hline № & $y_{I}$ & $y_{I I}$ & $y_{\text {med }}$ & $\Delta y$ & $(\Delta y)^{2}$ & $S_{1}^{2}=2 \times \Delta y^{2}$ \\
\hline 1 & 2 & 3 & 4 & 5 & 6 & 7 \\
\hline 1 & 1,0 & 0,98 & 0,99 & 0,01 & 0,0001 & 0,0002 \\
\hline 2 & 0,33 & 0,36 & 0,345 & $-0,015$ & 0,000225 & 0,00045 \\
\hline 3 & 1,0 & 0,96 & 0,98 & 0,02 & 0,0004 & 0,0008 \\
\hline 4 & 0,64 & 0,68 & 0,66 & $-0,02$ & 0,0004 & 0,0008 \\
\hline 5 & 1,0 & 0,98 & 0,99 & 0,01 & 0,0001 & 0,0002 \\
\hline 6 & 0,1 & 0,14 & 0,12 & $-0,02$ & 0,0004 & 0,0008 \\
\hline 7 & 1,0 & 0,94 & 0,97 & 0,03 & 0,0009 & 0,0018 \\
\hline 8 & 0,52 & 0,5 & 0,51 & 0,01 & 0,0001 & 0,0002 \\
\hline$\Sigma$ & & & & & 0,002625 & 0,00525 \\
\hline
\end{tabular}


$G_{\exp }=\frac{0,0018}{0,00525}=0,343 . G_{\text {table }}=0,68$ - thus, dispersions are homogeneous.

Dispersion of producibility

$$
s_{(y)}^{2}=\frac{\sum_{1}^{N} \sum_{1}^{n}\left(y_{q}-\overline{y_{i}}\right)^{2}}{N(n-1)}=\frac{2 \sum_{1}^{8}\left(y_{q}-\overline{y_{i}}\right)^{2}}{8}=\frac{2 \cdot 0,00525}{8}=0,00131 .
$$

At the chosen value of reliability $\alpha^{\prime}=0,95$ the limit of confidence interval:

$$
\Delta=t_{\text {table }} \frac{\mathrm{s}}{\sqrt{\mathrm{n}}}=4,3 \frac{0,00525}{\sqrt{3}}=0,013
$$

thus, $\bar{V}_{a x i}=0,64 \pm 0,013$.

A relative error: $\varepsilon=\frac{\Delta}{\overline{V_{a x_{\mathrm{i}}}}} \cdot 100 \%=\frac{0,013}{0,64} \cdot 100 \%=2 \%<5 \%$.

\section{Conclusion}

On base obtained results we assert:

- the coefficients of going out of velocity and temperature of air flow are determined;

- the biggest coefficient of going out of air flow velocity when the angle of slope of swirling plates is $90^{\circ}-1,9$ and the least when the angle of slope of swirling plates is $30^{\circ}-0,95$;

- the biggest coefficient of going out of air flow temperature when the angle of slope of swirling plates is $90^{\circ}-1,69$ and the least when the angle of slope of swirling plates is $30^{\circ}$ 0,84 .

\section{References}

[1] Taliev, V. N. (1978). Aerodinamika ventiliatsii. Moskwa: Stroiizdat.

[2] Hrimitlin, M.I. (1982). Raspredelenie vozduha v pomeshcheniah. Moskwa: Stroiizdat.

[3] Vozniak, O.T. (2001). Vplyv vzayemodii strumyn na povitrorozpodil u prymishchenni. Visn. $N U .2001,27-31$. Lviv: Lvivska politekhnika.

[4] Bankhid, L. (1981). Teplovoi mikroklimat pomeshcheniy. Moskwa: Stroiizdat.

[5] Vozniak, O., Kovalchuk, A. (2002). Efektyvnist' povitrorozpodilu zustrichnymy nespivvisnymy strumynamy. Visnyk Natsional'nogho Universytetu L'vivska politekhnika Teploenerghetyka. Inzheneria dovkillia. Avtomatyzatsia. 460, 157-161.

[6] Vozniak, O., Kovalchuk, A. (2002). Air distribution by opposite non-coaxial air jets. In VII Vedecka Konferencia s medzinarodnou ucastou Kosicko - Lvovsko - Rzeszowska, Kosice 2002 (173-178). Kosice: Faculty of Civil Engineering of TU. 
[7] Vozniak, O., Kovalchuk, A., Ivanus, Ye.,Kits, A. (2001). Povitrorozpodil u prymishchenni pry vzayemodii zustrichnykh nespivvisnykh strumyn. Visnyk Natsional'nogho Universytetu L'vivska politekhnika Teploenerghetyka. Inzheneria dovkillia. Avtomatyzatsia. 432, 31 - 37.

[8] Vozniak, O., Dovbush, O. (2000). Influence of indoor climate on a person heat exchange in a room. Zeszyty naukowe Politechniki Rzeszowskiej Aktualne problemy budownictwa i Inzynierii srodowiska; czesc 2 - inzynieria srodowiska. 2000, 441 - 447.

[9] Abramovich, H.N., Hirshovich, T.A., Krasheninnikov, S.YU., Sekundov, A.N., Smirnova, I.P. (1984). Teoria turbulentnykh strui. Moskwa: Nauka.

[10] Vozniak, O.T., Sukholova, I.Ye (2009). Deklaratsiynyi patent Ukrayiny No. 40185 vid 25.03.2009 , Biul. No. 6, 2009: Povitrorozpodil'nyk.

[11] Adler, Yu.P., Markova, E.V., Hranovskiy, Yu.V. (1976). Planirovanie eksperimenta pri poiske optimal'nykh usloviy. Moskwa: Nauka.

[12] Lovtsov, V.V., Homutetskiy, Yu.N. (1991). Sistemy konditsionirovania dinamicheskogho mikroklimata pomeshcheniy. Moskwa: Stroiizdat. 